\title{
The Near and More Distant Future Environment of Air Defence Missions
}

\author{
KRAJNC Zoltán ${ }^{1}$
}

\begin{abstract}
The author presents in this study the near and more distant future environment of air defence missions. He tries to find adequate answers to three questions in order to avoid prospective developments causing disadvantages for air defence experts and troops realising air defence. These are proliferation, the quick development of air warfare vehicles, and the widening airspace threats represented by civilian vehicles. In brief, air defence as defence activity is always at a disadvantage against the threats arriving from the air, but we must do our best to compensate.
\end{abstract}

Keywords: air defence, future threat, asymmetrical threats arriving from airspace, determinants of the future operational environment

\section{Introduction}

"It is very hard to predict, especially when we speak about the future", said once Nils Bohr, the famous scientist. This truth is experienced also by researchers who intend to predict the future of our security environment and the character and internal content of the wars (armed conflicts) of the future. Despite the difficulties, the cognition of the probable future and the creation of valid future images have great importance in the field of military affairs for the decision-makers.

Today there are scientifically based research papers using so many techniques to describe possible futures; however, we have to recognise that future research can be very "multi-layered" and can be only sustained with certain plausibility derived from present facts. The problem is very complex due to the fact that since the 1980s the relative stability of international relations has been replaced by very complex and difficult situations. Consequently, prognoses, circumstances and conditions of forecasting possible future scenarios have changed. Future research of scientific quality has to face a new situation: in society, in several fields of political and economic life, as well as in the field of military affairs, the stability and balance that existed earlier are becoming less and less characteristic.

The events and conditions standing for instability can be experienced in more and more fields. According to certain experts we have to calculate the duration of instable periods and take into account the fact that unexpected changes will take place more and more frequently, to the extent that instable conditions may become permanent. [1]

However, if instability is present in parallel with stable processes the culmination points induce epic changes. This means that in the security environment in addition to the old, fading processes, new ones are spreading. A spectacular example nowadays is Iraq, where

1 Lieutenant-colonel Krajnc Zoltán Ph.D., e-mail: zoltan.krajnc@gmail.com 
traditional phenomena (weapons, military techniques) belonging to a much earlier generation of warfare are present in parallel with the American warfighting culture using the most modern military technology. Guerrilla warfare based on terrorist actions goes together with network-centric warfare and effect-based operations. [2]

This complex situation induces implies that we will be forced to apply newer and newer methods beside the traditional methods of future research in the description of the security environment of the future. In the future research in security policy and in the forecast of the form and internal contents of prospective wars the governmental and non-profit research centres, also called "think tanks" of the United States are at the forefront. There have been some positive changes to level out American professional dominance in this field, as within the framework of the Allied Command Transformation, not long ago so-called centres of excellence. ${ }^{2}$ The main task of these centres is to provide future image and vision for NATO for the purpose of well-balanced medium- and long-term planning. [3]

Military thinking and decision-making processes have always included the claim to be able to do future research and make forecasts. It is enough if we have a glance at operational planning, the sequence in the commander's decision-making process, and we can establish that the prediction of the course of action of the enemy is also based on prognosis-making processes integrating elements of general evolution theory and scenario-making methods. This can be observed much more in the elaboration of medium- and long-term plans of military development. Thinking further about the above mentioned analogy, in the case of planning a longer campaign or a complete war, the necessary decisions can be prepared only based on a future image elaborated with scientific thoroughness. [3] [4]

The analysis of the security environment, the time horizon of the examination of potential threats and trends usually result in studies of medium-term (5-10, perhaps 15 years) and of much longer term (even 20-40 or 50 years) forecasts. [3]

We can encounter the results of the analyses in shorter terms in the first chapters of security strategies, strategic conceptions and allied and national doctrines of integrating character, where the main messages are explained further. Analyses of such terms, usually, if executed by strictly scientific methods are usually made with the use of classical prognosis ("forecasting"). This prolongs future based on the tendencies of the near past and on the experiences and phenomena of reality available up to now. [3]

Here we present the most important elements of future images (strategies, official studies summarising trends, etc.) based on the above summarised methods of future research.

2 The first one of such research centres is the Joint Air Power Competence Centre (JAPCC) established in Germany, whose main assignment is long-term forecast, to discover the trends of air and aerospace warfare, and to contribute to the elaboration of the strategic conceptions of NATO. 


\section{The Basic Change of the Strategic Environment: Asymmetrical Threats Arriving from Airspace}

The air component responding to the succinctly summarised trends of threats is basically constituted to counter threats arriving from the air. The development of air assault equipment and the process of their proliferation will be explained further in detail. [3] It is the increasing freedom of the transfer of the technology that makes it possible for more and more states and even groups to produce harmful devices, not to speak about the dangers caused by the arms trade. ${ }^{3}$

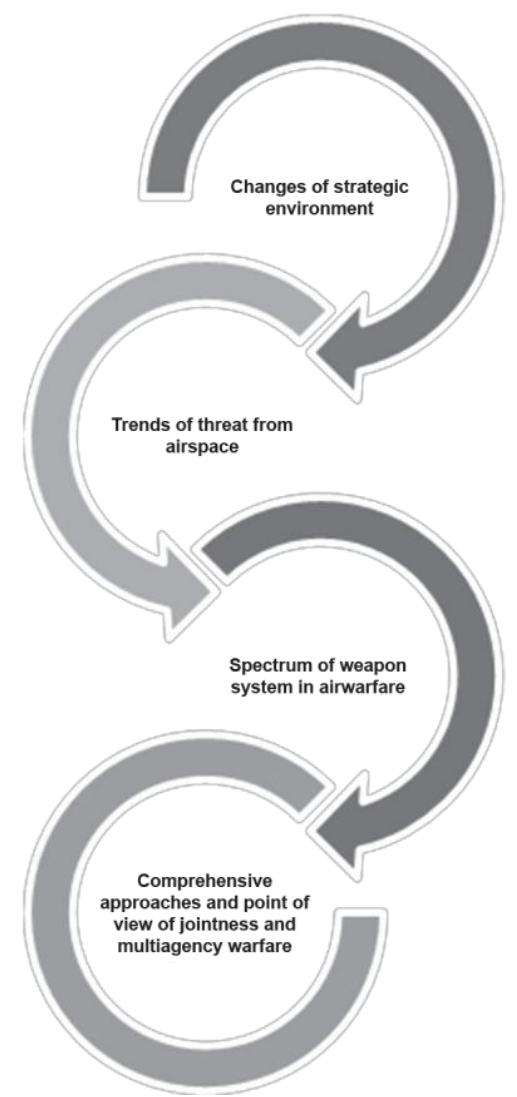

Figure 1. The major determining factors of environment of air defence. (Edited by the author.)

A Terror threat coming from the air cannot be ignored, especially after the attacks against the World Trade Centre and the Pentagon.

3 Last year the news reported an incident when the Spanish Navy "caught" a ship transporting the main elements of ballistic missiles along the Spanish coasts. The addressee was probably one of the Middle-Eastern states or terrorist organisations. 
The increase of the terror threat coming from the air can be observed even today, since well-organised terrorist groups after thorough planning, are able to consider every factor. They also may acquire destructive weapons and carriers that are able to cause considerable damage (poisoning, infection, psychical pressure, etc.). They can also use legally available aircraft or civilian aircraft accessed on the ground or hijacked in the air whose application for destruction mean a serious threat.

The situation is exacerbated by the fact that these criminal groups may be able to install warheads (poison, explosive) in "small aircraft" and execute terror attacks with them against appointed targets. Apart from the small aircraft platform, it is imaginable that they will acquire more serious technologies and use helicopters, drones or, according to the darkest version, ballistic missiles. The complexity of such a terror attack and the difficulty of the defence against it are shown by the fact that attacks can be initiated not only from beyond the borders, but also from within the borders of a given country, which is very disturbing as for the calculation of the reaction time.

\section{Airspace Challenges Deriving from Regional Instability}

Military challenges and threats in the classical sense have decreased however, instability is a possibility for the appearance of many forms of air threats. The platform, the targets and the destructive material can be similar to the above mentioned: the most likely is the use of small (sport) aircraft.

Certainly we do not only have to account for terror attacks from distant regions, since organised crime (drug related, weapon smugglers, fissile material and refugee smuggling, etc.) and the violation of the international rule of aviation (e.g. its "Balkanian"-type application) can also endanger the security of the airspace of the Western world. [4]

The very quick spread of mass destruction vehicles and their carriers and the technological transfer of their production mean a potential danger to our homeland. It is a well-known fact that the most important terrorist organisations have already made attempts to acquire fissile material, and such materials may be and might have been smuggled out of some successor states of the Soviet Union.

As for our homeland, air threat endangering the Hungarian contingent during military operations outside the area of the country is a very important element. Certainly, it cannot be separated from the threat endangering the coalition forces, since it is an organic part of this threat. Furthermore, the participation of our homeland in such operations can also induce attacks against Hungarian targets from state or sub-state parts of the conflict, which can be very dangerous if the given state (group, organisation) owns nuclear weapons or is even able to produce "dirty bombs".

Nowadays we speak very little about the security risk that evolves with the appearance of portable (portable by man) air defence missiles in illegal hands, and its application against civilian or even military air vehicles or the threat of which can cause very serious damage. [4] 


\section{The Spectrum of Air Raid Vehicles as One of the Main Determi- nants of the Future Operational Environment of Air Defence}

Apart from the envisioning of future security challenges, technological and proliferation trends, the making of prognoses can more and more come to the forefront in military future research. This may be the basis for the elaboration of potential air threat alternatives in the preparation of the development of the air force. Although the main assignment of air defence has not changed in the last decades, the spectrum of its threats has considerably been restructured, changes of emphasis have evolved. The earlier understanding of air defence, well-known from the past, can be described as the classical air defence and its version that developed further in an evolutionary way, into "extended air defence". ${ }^{4}$

We can understand why this fairly new concept appeared in the theoretical system of air defence, what is behind it and what qualities it contains through the review of the main categories of air raid vehicles and their tendencies of development. The spectrum of air threat is constituted by air warfare vehicles that we can calculate as potentially dangerous to the objects to be defended. It is practical to analyse, besides the dangers deriving from the application of fixed-wing and rotary-wing aircraft meaning traditional threat with risks deriving from the application of ballistic missiles, manoeuvring robotic aircraft, unmanned aircraft and surface-to-air missiles.

The quick technological development, the harmful proliferation of weapons of mass destruction and their means of delivery can be realised with fairly cheap technology. While in the past both the centre of gravity and the focus of air defence were aimed at the armed air vehicles, aircraft and helicopters controlled by a pilot, nowadays more and more attention needs to be paid to pilotless air vehicles, ballistic missiles and other air vehicles. The attached diagrams make it clear that certain air warfare vehicles mean serious threats. Compared to the prizes of the development and maintenance of fixed-wing aircraft based on high technology, it becomes clear that recent threats can be produced and deployed en-masse at a fairly cheap price thus giving a serious challenge to air defence. [5]

\section{Fixed-Wing Aircraft}

Enemy aircraft is the most classical air threat for air defence and the objects to be defended, and they will probably remain a very important element of the air threat spectrum in the future.

We classify the following categories as fixed-wing aircraft: bombers, fighter-bombers, fighters and reconnaissance, cargo and battle aircraft. According to the newest trends of technological developments air forces do their best to deploy multifunctional, universally applicable aircraft.

Due to the wide range of the applicability of aircraft, they are applied in each segments of air warfare, and they can execute strategic air operations, attack and defensive counter air operations, air interdiction, close air support, electronic warfare and air reconnaissance.

The designers of air defence can count on enemy fix-winged aircraft attacking targets of big value, like sea harbours, airports, platoon groups, air defence artillery units, command and control centres and logistical bases.

4 Extended Air Defence - EAD 
The weaponry and ordnance of fixed-wing aircraft provide a very wide spectrum of application as they can carry machine-gun, automatic cannon, guided and non-guided surface-to-surface missiles, air-to-air missiles, reconnaissance and electronic fight containers. Some of them are also able to launch robotic aircraft the air defence must also take into account. [6: 2-8]

\section{Helicopters}

Since the Korean War helicopters have been playing an increasing role in warfare. In the beginning they were applied for reconnaissance and artillery fire control, later for the transportation of troops and material. Today they have become usable in the full spectrum of air warfare, as a result of technical and warfare specialisation.

This fact was displayed by the first air raid of the Gulf War in 1991 in which the most important radar points of the Iraqi air defence forces were eliminated with AH-64 Apache helicopters thus paralysing the command and control system of the air defence, with which they decisively contributed to the success of the operation to neutralise the air defence forces.

Attack helicopters were applied by the French for the first time in the Algerian Crisis in 1959. After that the theory of its application, warfare with attack helicopter, started to evolve, and this process was justified by the "attack, transport and armed helicopters" applied enmasse in the Vietnam War. Due to its versatility, survival, and anti-tank ability, helicopters are ideal air vehicles to support warfare and operations of ground forces. In most countries we can consider attack helicopters a cheap, but very effective alternative and the so-called armed (armed, multirole) helicopter the main asset of direct air support for troops.

Another indispensable battle element of mobile air troops and air descent operations is the transport (multi-role) helicopter with which it is possible to transport the forces to the target area, and like this the (special) forces penetrating in the depths of the enemy can disrupt the command and control system of the enemy, occupy objects of key importance and destroy warfare elements of decisive importance.

Search and rescue operations in war time, peace time and air evacuation (the transporting of the casualties home) nowadays cannot be imagined without modern helicopters. With the help of the aircraft with special equipment the air force is able to rescue the crew of the aircraft (helicopter) and to transport the casualties off the battle field.

The development of air defence helicopters is also a present-day development trend, with which the annihilation of aerial vehicles of low velocity (helicopters, aircraft, balloons) is planned.

Military experts recognised early that helicopters can be a prominent vehicle of warfare; therefore it is equipped with a wide range of board weapons and ordnances. It can bear the following weapons (or interior or exterior ordnances): machine gun, automatic cannon, guided and non-guided missiles, grenade launchers, air-to-air missiles, reconnaissance and electronic fight containers.

For ground-based air defence systems the application of helicopters can mean a serious threat as the vehicles attack in pairs, exploit the camouflage opportunities provided by the environment, and are able to approach the target area flying close to the ground. The annihilation of warfare vehicles executing operations mean a very great difficulty to air defence systems operating on the principle of radial velocity measurement (applying Doppler-frequency). The combat against helicopters is supported by the fact that their application depends on the weather and the given time of day, and its relative loudness makes it easier to locate it with traditional devices. [6: 2-6] 


\section{Ballistic Missiles}

Operation Desert Storm of the Gulf War provided the designers of air defence weapon systems and air defence operations with a very important conclusion. The Iraqi soldiers, despite the relatively small effectiveness of warfare aircraft, applied ballistic missiles and robotic aircraft attacking ground targets with relative success. The experiences of the war revealed what challenges the Republic of Hungary and its allies must face in the future.

The high expenditures of the development, maintenance and application of fixed-wing aircraft and the theoretical possibility of losses to the air forces of NATO member states makes it very attractive for several countries to want to acquire ballistic missiles. The press often calls the missiles a real threat in potential contemporary crisis and describes them as "the long stick of poor countries". Their danger is certainly in their relatively low costs $(0.5-$ 1 million USD) and the relative simplicity of the manufacturing technology. This weapon system that can be considered the successor of the V-2 rockets of World War II was developed by the Soviets in the 1950s (under their NATO code name: SCUD), and several of its modifications became widespread throughout the world.

The ballistic missiles can cause destruction to an unacceptable degree by aiming at large population centres, or by the application of non-traditional warheads. Furthermore, it cannot be ignored that the deployment of the missiles or the threatening of their application can have severe psychological effects that were also proved by the Gulf War, when the Iraqi government was threatening Israel with SCUD-missiles.

The ballistic missiles can be applied as vehicles of "first strike" or of the so-called "revenge attack". Their velocity and the variability of their launching make them suitable for unexpected attacks. The ballistic missiles make it possible for the applying countries to project their military forces long distances, beyond their borders, with which they can also re-structure the battle fields, since commanders must use considerable resources to neutralise the rocket threats. It also means a separate problem that the majority of possible aggressor nations in potential crisis areas own weapons of mass destruction together with ballistic missiles as means of delivery.

The vertical launching systems have a high degree of survival ability, especially when they are applied in darkness or at low visibility. The launching vehicles of great mobility are able to occupy hidden launch facilities, making it very difficult for forces and vehicles to locate and annihilate them. The surviving ability of the launching vehicles means that in the case of a possible crisis management or of an operation outside NATO area the rocket threat can stay permanent during the whole involvement.

The warfare ability of these missile systems, due to their low accuracy and precision, is not very relevant; however, we cannot forget about their low range, considerable survival ability, their ability to carry weapons of mass destruction, and their psychical pressure on the population. [6: 2-1]

The defence against ballistic missiles can be really effective only if an active air defence fight is completed with the activity of traditional (special) forces assigned to locate and annihilate the launching vehicles. If the Republic of Hungary would like to meet the challenges represented by ballistic missiles, then it should think about acquiring a missile defence system and the adaptation of the theory of application. 


\section{Cruise Missiles (Manoeuvring Robotic Aircraft)}

The roots of present-day manoeuvring robotic aircraft, similarly to ballistic missiles, can be found in the German military industry of the Second World War. The V-1 rocket of the Wehrmacht and the Okha type robotic aircraft of the Japanese army served as the basis for the post-war American developments. This vehicle was in the beginning used as air defence deployed by the Air Force and the Navy in the 1950s. The development of robotic aircraft continued, and the vehicles launched from ground-, air- or sea-based systems were developed for strategic (nuclear) attacks during the bipolar world order.

We call robotic aircraft those vehicles that are equipped with wings of different types and categories, stabilizers and engines utilising the oxygen of the atmosphere, flying along a programmed orbit or flying with remote control. Usually, robotic aircraft approach the target to be annihilated by flying along the surface (e.g. with TERCOM navigation) during the whole period of the operation, or in the beginning they fly along a ballistic orbit then return to the airspace flying along the surface.

Robotic airplanes - within the class of the tactical rockets, together with pilotless airplanes and air-to-surface rockets - are classified as so-called "tactical aerodynamic rockets". As for the development of robotic aircraft, besides the application of more and more modern technology, we can also observe a trend according to which it is not the vehicles of high technology that are being developed, but similarly to the "weapon of the poor people", the ballistic missile. First and foremost with the transformation of anti-ship vehicles and with the use of various GPS-based devices available off the shelf, cheap weapon systems of limited warfare capability are created.

The limited ability of accuracy and precision concerns the probability of reaching the target. However, the importance of the weapon system is given by the fact that in possession of this type of relatively cheap vehicle the power relations of the region can be changed, not to mention the fact that robotic aircraft are even able to carry weapons of mass destruction and have a survival ability of great degree.

As for the size, the form, the mode of control or the types of weapons carried by them there is a very wide variety of manoeuvring robotic aircraft in use, and their range is from $30 \mathrm{~km}$ up to $1,000-3,000 \mathrm{~km}$. After the short-range anti-ship versions several countries are developing manoeuvring robotic aircraft capable of attacking ground targets, and in their control GPS-based satellite navigation technology can also be applied. The aim of the development of the future technologies of manoeuvring robotic aircraft is to increase the range and improve the accuracy of these vehicles.

Usually the cruise missiles are planned to be applied in the destruction of non-mobile targets that do not have strategic importance, and similarly to ballistic missiles they play a serious psychological role and can maintain permanent threats in crisis areas. [6: 2-3]

\section{Unmanned Air Vehicle (Pilotless Aircraft)}

We classify the unmanned air vehicles of remote control and the programmed unpiloted vehicles, the so-called drones, as pilotless aircraft. These vehicles can be characterised by the fact that they are easy and cheap to acquire and produce, and can be used in a number of ways. They can be applied for reconnaissance purposes, electronic warfare, for strikes 
against ground (water) targets, and they can participate in the neutralisation of air defence systems and can be involved in artillery fire control and deception.

It is a great advantage of pilotless aircraft that it demands much less crew training than aircraft, and its application increases the morality of warfare by the fact that the missions do not risk the life of the pilots.

Due to its small size, its effective radar wave reverberating design, its low flying profile, it is a very difficult assignment for air defence systems to annihilate pilotless aircraft. [6:2-5]

\section{Air-to-Surface Missiles}

Tactical air-to-surface missiles - similarly to robotic aircraft and pilotless aircraft - belong to tactical aerodynamic missiles. According to their control systems they can be radio-guided, self-guided against radars, half-active laser guided, electro-optical and TV-guided. Due to their large velocity and small effective radar cross section these targets are also very difficult to locate, follow and annihilate.

We have to especially deal with the anti-radar missiles to be applied against radiating radio-technological devices (radars), which are the most important equipment for the neutralisation of air defence systems, because it means a very serious threat, since with its application the enemy can raid our reconnaissance and fire control radars from a relatively great distance and from outside the fire zone. Anti-radar missiles can have a very destructive effect if they are applied together with deceiving pilotless aircraft used for the activation of radars. [6: 2-4]

\section{Concluding Remarks}

As we have already written in the beginning of our article, it is very difficult to "predict", but as Kossuth Lajos said: "The past is the mirror for the future." We cannot ignore and neglect the elaboration of longer-term prognoses. We must consider our possibilities and abilities, and deal with the prospective tendencies and the problems indicated by them. We have to find the adequate answers to three questions in order that prospective development should not cause drawbacks to air defence experts and troops realising it. These are proliferation issues, the quick development of air warfare vehicles, and the widening airspace threats represented by civilian vehicles.

As for the proliferation of mass destruction vehicles, the problem first and foremost requires a non-military solution. It is a political, diplomatic and economic effort that is able to hinder and slow down this very dangerous and harmful process, even if it is not able to stop it. The attention of state and economic decision-makers must be turned to this circle of problems, and we should participate in the hindering of proliferation.

The search for the "air space answer" to the quick development of air warfare vehicles is nowadays on the beam. The building of early reconnaissance and forecasting systems provides a suitable basis for the maintenance of active and effective ground- and air-based air defence systems. At the moment it has limits of expenditures rather than technological limits. The extension of the local air defence systems into regional systems in time and space and via the increase of security level can be effective. The alarm services and situations of suitable quantity and quality can provide sufficient defence, even against surprise-like aggression. 
Air defence is applied, not element by element, but strictly as an integrated system. Together with all necessary components it can give a suitable answer to current military challenges and threats.

Nowadays the applicability of civilian aircraft as air raid vehicles represents the most dif- ficult problem. There is no perfect, effective solution against terrorist operation in every sit- uation. The possibility of acquiring small civilian aircraft, as mentioned above in the article, and their configuration into weapons is unfortunately too simple and not expensive at all. The restriction or ad absurdum the complete prohibition of private aviation is not the best solution in the same way as the building of the continuous and direct air defence of the threatened targets and objects. The first solution would generate nearly unsolvable legal problems, while the second would mean unendurable expenditures. In these fields, the air defence seems to be the "loser". The available military vehicles and possibilities do not and cannot grant a satisfactory solution, mainly due to the problems caused by the very narrow reaction time. In the same way as at the dangers caused by proliferation, in this field there is also state inter- ference and regulation necessary, completing it with strictly regulated military contribution, and as a final step, with the annihilation of suspicious or obvious enemy air targets as soon as possible. Undoubtedly, $11^{\text {th }}$ September, 2001, redefined many things for possible activity against "civilian" air vehicles.

To sum it up, air defence as defence activity is always at a disadvantage against the threats arriving from the air, but we must do our best in order that this disadvantage decrease.

\section{References:}

[1] Magyarország Nemzeti Katonai Stratégiája. www.kormany.hu/download/a/40/00000/ nemzeti_katonai_strategia.pdf (downloaded: 1304 2015)

[2] JOBBÁGY Z.: Clausewitz and the Gestalt of War. AARMS, 121 (2013), 117-128.

[3] NOVÁKY E.: A jövőkutatás módszertani megújulása. https://miau.gau.hu/miau/05/jkut.html (downloaded: 1304 2015)

[4] JOBBÁGY Z:: On the Shifting Balance of Command and Control: A Tale of the Genes and Xenophon. Science and Military, 61 (2011), 28-34.

[5] IFPA: Air, Space, and Cyberspace Power in the $21^{\text {st }}$ Century. $38^{\text {th }}$ IFPA-fletcher Conference on National Security Strategy and Policy, Washington, D.C.: Ronald Reagan Building and International Trade Center, January 2021, 2010. www.ifpa.org/pdf/USAFreportweb.pdf (downloaded: 1304 2015)

[6] TÓTH S.: A képesség tervezés nemzetközi és nemzeti aspektusa. Kihívások, fenyegetések, az erőszak kezelése, erőszak alkalmazása. Képesség alapú légierő és a képességfejlesztés nemzeti és szövetségi feladatainak összehangolása, Repüléstudományi konferencia, Szolnok, 2005.

[7] FM 3-01 (FM 44-100) U.S. Army Air and Missile Defense Operations. https://info.publicintelligence.net/USArmy-AirMissileDefense.pdf (downloaded: 1304 2015)

[8] FM-44-100 Air Defense Artillery Reference Handbook, 2000. Final Draft.

[9] KRAJNC Z:: A légierő alkalmazásának alapkérdései. Új Honvédségi Szemle, 7 (2005), 87-98.

[10] KRAJNC Z.: A légierő megváltozott szerepe a XXI. század hadviselésében. Budapest: Geopolitikai Tanács, 2006. (kutatási jelentés) 